\title{
RESPONSIBLE INVESTING: A STUDY ON NON-ECONOMIC GOALS AND INVESTORS' CHARACTERISTICS
}

\section{RENUKA ${ }^{1}$ SHARMA, KIRAN MEHTA ${ }^{1}$, VISHAL VYAS2*}

1. Chitkara Business School, Chitkara University, Punjab, India.

2. ABV-IIITM, Gwalior, Madhya Pradesh, India.

* Corresponding Author: Vishal Vyas, ABV-IIITM, Morena Link Rd, IIITM Campus, Gwalior, Madhya Pradesh (474015), $₫$ vishalkvyas@gmail.com

\begin{abstract}
The current research has explored the responsible investing behaviour of Indian investors. The terms like socially responsible investing, non-economic goals, ethical investing, and responsible investing are interchangeably used by researchers. The notion of responsible investing is not attuned with the idea of rational investing. The responsible investors are not confined to financial gains only as it is observed in the case of a traditional or conventional investor. There are certain attributes or characteristics of an individual which affects their responsible investing decisions or non-economic goals. The prime objective of the study is to establish the relationship between non-economic goals and different characteristics of individuals. For this, we have used a standardised scale to measure responsible investing behaviour. The research is based on primary data for which a sample of 378 individual investors was considered. The findings are obtained through hierarchical multiple regression models. The findings of the study are useful for fund managers, regulators and researchers as the study have provided useful insights regarding the behaviour of Indian investors for responsible investments.
\end{abstract}

JEL classification: G41, G40, D91

Keywords: Non-economic goals, Socially Responsible Investing, Religiosity, Collectivism, Environmental Attitude, Materialism.

\section{Introduction and Background}

The contemporaneous global ecosphere is anticipating a remarkable success story of the Indian economy in the contiguous future. Many companies in India have made their place in topmost global companies. These companies are mindful for their responsibility towards environmental, social and governance (ESG) concerns. A global company must understand that all international organisations, as well as international investors, are worried about ESG risk in emerging markets. Countries like Brazil, China, and South Africa are actively focusing on ESG challenges and making various attempts to create an investment climate to promote sustainable portfolio investment. The introduction of various ESG indices across the global bourses indicates the relevance of the issue on responsible investing. World-renowned companies like Standards \& Poor's, MSCl and Thomson Reuters are some of the leading examples, which have launched a large number of ESG indices for various counties, and Emerging markets. The countries using ESG, sustainability or responsible investing indices have already recognised that an investor while constructing his portfolio, do not depend exclusively on risk-return characteristics of different asset classes but also employ certain qualifiers to incorporate Economic, Social, Governance (ESG) linked considerations to supplement their investment decision. The next obvious question to this discussion can be to examine the 
difference in the performance of socially responsible investments and other investment classes available in the market. If the socially responsible investments cannot beat the market, then the whole idea of putting so much thrust to endorse responsible investment avenues will be palisaded. The existing literature on the performance of socially responsible investment (SRI) gives variegated cues to investors' preference for SRIs. Generally, the investors appreciate investing in SRIs if their riskreturn profile remains at a parity level when compared with other investment alternatives. When a company follows eco-friendly practices and takes care of its employees, then it can outperform the market too (Edmans, 2011).

Statman and Glushkov (2008) found evidence for SR funds in US market and indicated the poor performance of these funds in comparison to the market benchmark. Renneboog et al. (2008) depicted the poor performance of socially responsible (SR) funds in seventeen countries of Asia, Europe, North America, and Oceania. Cortez et al. (2012) also revealed similar results for several European countries, the UK, and the USA. In a research-based on Netherland, the authors investigated the investors' behaviour for the socially responsible bank. The findings of the study revealed that socially responsible investors expect higher returns from SRI funds in comparison to other investments (Baver\& Smeets, 2015). The researchers have also revealed that sometimes the socially responsible investors accept the lower return than market returns due to their social preference (Riedl and Smeets (2014).The selection of responsible investment avenues implies that the investors are more fretful about the accomplishment of their non-economic goals rather than fulfilling economic goals. Mclachlan et al. (2004) established the difference in the investment decision criterion of conventional investors and socially responsible investors. The study revealed the difference between beliefs of socially responsible investors and conventional investors.

Gambhir et al. (2017) emphasised that there are many social and intangible gains associated with socially responsible investments. Therefore, under such a situation, one should use social return on investment (SROI) instead of using a conventional method of calculating return on investment (Rol) for the valuation of the investment. For the past two decades, investors have revealed a burgeoning concern in (often equity-related) different instruments of SRIs (Schueth, 2003). These mounting tendencies can be noticed through an increase of 10-15 per cent in the market share of equity SRI products in the USA and 10 per cent increase in Europe (Robeco, 2008). In the wake of the recent financial crisis, the growth in SRI has plunged (European Sustainable Investment Forum, 2012) which confronted the concept of rational investment by stressing on the issue that short-term financial success. It may have extended the negative consequences not only on social goal setting but also for economic objectives of the investors (Giannarakis and Theotokas, 2011). Ortas (2012) revealed that during a bullish market scenario, the ethical investors need not worry about the overall performance of their socially responsible investment. However, in case of financial turmoil, ethical investors were not able to fetch the same amount of profits due to several institutional and social factors. In a study based on Brazilian firms following sustainable practices, the authors examined the difference in their financial performance with the firms, which are not following sustainable practices. Remarkably there was no difference in the financial performance of companies based on their investment in responsible activities. However, the difference in the performance was due to other factors like sector representation etc. (Santis, 2016). But the results obtained for Italian firms contrasted with Brazilian firms. The more investment in environmental practices reduced the profit of 45 waste management companies in Italy (Bartolacci et al., 2018).

However, like other emerging markets, SRI funds have not been able to depict substantial growth in India. In the current scenario, socially responsible funds are almost non-existent, and therefore, there would be uncertainty in terms of the SRI products. The information related to SRI funds is also completely new to the investment market. Investors think these funds to be riskier, but in reality, these funds are less risky. The growth of such funds is not as fast as found in western countries; therefore, investors perceive these funds to be riskier and are less tolerant in such an opaque investment environment. The evidence of socially responsible behaviour of investors can be observed during the Vietnam war when the investors did not consider firms having any linkage with 
this war. The Social Investment Forum (1995) has also indicated the increasing concern for social criteria among US investors while selecting an investment criterion.

Likewise, the increasing concern for SRI in the context of Japanese investors is also reported at the beginning of the 20th century (Hiraki et al., 2003). The researchers said that SRI is a new area, and it will take time to evolve. Investing in pension funds allocating their funds in SRI based portfolios does not benefit the investors in Japan (Jin et al., 2006). In initial research based on the Domini 400 Social Index, the author revealed that the investors need not compromise with their belief and ethical values. They can invest in a fund which has a social concern, and it can outperform the market portfolio too and thus without compromising with the returns, the socially responsible funds can be considered as an investment alternative (Saver, 1997). The firms which are screened for socially responsible behaviour can prove to be more robust than their competitors in terms of profitability and stability (Herremans, Akathapom and Mclnnes, 1993). McGuire, Sundgren and Schneeweis (1988) exhibited that the employees' loyalty increases in case a company follows socially responsible practices. Usually, firms are concerned for increased cost, lower profits, less scope of diversification and additional cost in identifying socially responsible opportunities while executing socially responsible screening (Temper 1991). Socially responsible mutual funds reported lower returns than the market benchmark (Goldberg, 1993; Mueller (1991). The initiatives taken by UNCTAD, Global Compact and Principal of Responsible Investment (PRI) during the first decade of 20th century to establish Sustainable Stock Exchanges (SSEs) is an indicator of future of responsible investing and responsible financial markets.

The number of SRI funds is very less in India. "Tattva", the socially responsible equity investment program by Yes Bank, is one of few such examples. Other noticeable SRI mutual fund is ABN Amro Sustainable Development Fund, which was launched in 2007. It was India's first SRI fund. The companies, which become the part of this fund, are screened by CRISIL on an ESG scale. The lack of ESG (Economic, Social, and Governance) measurement and disclosure practices and code of conduct are the major reasons for the lesser number of SRI funds in India. In 2008, an ESG index called S\&P ESG India index was made, which is composed of 50 best-performing equity stocks of Indian market on three ESG parameters. Companies like Wipro, Infosys, Mahindra \& Mahindra, ITC, TCS, L\&T, Tata Chemicals, ACC, HCL Technologies and Dr Reddy's Laboratories are part of this index. Similarly, many other indices based on environmental, social and governance performance of companies were launched in Indian stock markets. These include Nifty 100 ESG index, Nifty 100 Enhanced ESG index, Nifty 100 Sector ESG Leader, and S\&P ESG 100 index etc.

The disclosures of ESG parameters for companies are not similar in developed and emerging countries. The European, UK and US markets have shown more stringent practices of following the disclosures related to ESG in comparison to the rest of the world. The concept of socially responsible investment is actually transmuted into ESG practices. The ideology of investing in SRI has become more customary with the mounting significance of ESG disclosures around the world. All institutional investors, portfolio managers and cognizant individual investors give due attention to ESG compliances by a company before investing in them. In a country like India, where individuals are highly motivated by their personal values, a company's assurance to meet ESG challenges can help it to find a place in the portfolio of investors. The responsible investment by investors speaks about their priority for non-economic goals in place of economic goals. Further, the individual investor's economic and non-economic goals are affected by various factors, which are not similar to what has been identified in the western world (Mehta, 1994). The study indicated that the desire for social achievement is the primary determinant of an individual's behaviour in India. Pareek (1986) indicated that the need for an extension is the primary determinant of individual behaviour in India. India is a diverse country with individuals having many languages, religions, castes, communities, and other social and cultural aspects. Under such a diverse environment, an individual is influenced by various psychic and spiritual benefits he/she is going to get from the investment. The socially responsible investing behaviour of Indian individuals is the result of the impact of various forces. Consequently, it is critical to know which factors imitate the individual 
investor's behaviour towards SRI decisions in India. Moreover, the role of the retail investor in the Indian equity market is noteworthy during 2018-19. Even after a volatile market scenario, the mutual funds reported a surge of 11.4 per cent in their assets due to the increased participation of retail investors. The growth in mutual fund in cash market segment is also indicative of individual investors' contribution to the growth trajectory of the Indian stock market. The contribution of mutual funds in the cash market on the NSE platform got increased from 7.3 per cent (2017-18) to 7.5 per cent (201819). The individual investors are holding more than 95 per cent of total AUM (asset under management) of both public sector and private sector mutual funds (source: Security Exchange Board of India (SEBI) Annual Report 2018-19, www.sebi.gov.in). Therefore, the existing trend of retail investors' participation in Indian stock markets and potential for enormous space to augment their contribution insinuate to study the individual investor behaviour more thoughtfully.

In this milieu, the present study attempts to comprehend characteristics of the Indian investors affecting their non-economic goals, i.e. ethical goals of investment. A study conducted by lyer and Kashyap (2009) on investor characteristics postulated that social investing efficacy (SIE) affects the individual's characteristics to take non-economic investment decisions. This study indicated that the SIE characteristic of the investors makes them believe that a company remains stick to all those essential values, which are considered by their investors.

\section{Literature Review and Theoretical Background}

The existing literature on individual investors' characteristics affecting socially responsible investing behaviour is largely based on five significant attributes obtained from extant literature available on related issues. These attributes are 1) Collectivism, 2) Religiosity, 3) Materialism, 4) Environment Attitude, and 5) Risk Tolerance (it is categorised into individual risk propensity and individual risk propensity). Most of the studies revealing above said characteristics of individual investors are based on the US market. Broadly, the individual investors' investment goals can be labelled as economic goals and non-economic goals. Any SRI fund or SRI scheme introduced for investors entails an evident thoughtfulness of above cited five features, as these are likely to affect the individual's investment decision.

For example, Collectivists always emphasised on group welfare; hence, in such a culture, pro-social behaviour is given high priority (Hui and Triandis, 1986). Douglas and Wildavsky (1982) developed Cultural theory of risk and mentioned that the cultural values, social institutions, and the ways of life (hierarchical, individualist, egalitarian, and fatalist) influence the risk perceptions of individuals. The five attributes, as mentioned above, have been considered by past researchers incessantly to examine the behaviour of socially responsible investors and their non-economic goals.

Previous evidence suggested that Western culture is more individualistic, and religiosity is in second control. Ger and Belk (1996) revealed in a cross-cultural study and found that dramatic cultural or social change events bring a higher level of materialism. They also found that materialism exists across distinctive cultures, but the extent of materialism was classified as different between developing and developed economies. Likewise, the study also concluded that in Western culture, investors' attitude to the environment is formed by development in science, and it promotes risktaking among individuals as it laid emphasis on individual freedom. The ESG criteria affect the valuation of firms too. In a research-based on five-factor mode, the authors incorporated sustainability premium as an additional factor loading and found a negative relationship between the cost of capital and sustainability performance (Gregory, Stead \& Stead, 2020). The researchers have used experimental methods to investigate investors' behaviour towards socially responsible investments. In one such study based on Japan, the investors were given a certain amount and asked to select an investment alternative among two equity investment avenues. The investors were required to make an investment decision based on risk, return and money spent on corporate 
social responsibility by two firms. The purpose of the study was to capture the psychological features of potential SR investors (Nakai et al., 2018).

In the Indian scenario, greater emphasis is given on collectivist behaviour because the history of India has shown a trend of families being more prominent in size and multi-generational. In a study, Baver and Smeets (2012) concluded that deliberation in social responsibility investment by investors while allocating their money could be caused by the beliefs and by the preferences of the investors. Both religion and religiosity have an impact on the economic set of a country. The religious values and religion have stood at the marketplace. The religious belief results in religion motivated enterprises (Klein, Laczniak and Santos, 2016). Religion has an impact on the consumption behaviour of individuals, too (Hirschman1982). In a country like India, religion is discussed for the conduct of a political party (BJP) with their governance style (Corbridge and Harriss 2013) while Du et al. 2014 examined the impact of religion on the conduct of a business. The spiritual values, along with organisational theories, give direction to businesses in taking various decisions (Brophy 2015; Cui, Jo, and Velasquez 2015). Renneboog et al. (2011) studied the monetary flow of ethical funds around the globe by adopting Petersen's approach (2009) and found that US ethical funds were less responsive to returns than US conventional fund flows implementing the difference and GMM techniques.

In addition to above, various evidence has been obtained in the studies conducted by Dhawan et al. (1995) where Indian investors have demonstrated more intensity for the attribute of collectivism as they are depended upon each other to take their decisions while it is not identical in the case of American individuals. India is a diverse country, and within a specific group, viz., people belong to a specific caste, language, religion, or cultural background, etc., individuals help each other. Therefore, collectivism is found as a significant attribute of Indian individuals. Shavitt et al., (2006) have stated four dimensions of the individualism. These are Vertical individualism (VI), Horizontal Individualism (HI), Vertical Collectivism (VC) and Horizontal Collectivism (HC). The horizontal individualism places an individual's tendency to be independent as a priority, whereas vertical individualism put emphases on the prominence of competition. Further, horizontal collectivism emphasises the importance of social relations with equality for individuals and vertical collectivism emphasises the importance of social relations with superiors. These four attributes are found in individuals and vary from one group to another group. Thomas and AU (2002) documented that vertical collectivism and horizontal individuals are the outcomes of cultural differences. Misra Srivastava \& Banwet (2019) emphasised the place of religiosity and consciousness in predicting the investors' behaviour. The researchers also revealed that a religion-based workplace develops spirituality at the workplace and bring resilience instead of emotional tumult. Nevertheless, religious beliefs may result in cognitive biases which can be a cause of irrational thinking too (Pennycook et al., 2014). Zuckerman et al. (2013) also divulged an inverse relationship between intelligence and religiosity. The religiosity can result in risk aversion behaviour of investors. The investors having some religious belief tend to avoid raising debt and prefer to invest in intangible and fixed asset securities (Jiang et al., 2015).

In India, nature is revered, and rudiments of nature are termed as God. Hence, religiosity and environment consciousness may be associated in the Indian context, and somewhere such beliefs may affect an individual's rational economic choices. Religion plays an important role in day-today decisions but fewer roles in economic decisions. Environmental attitude includes the preservation of natural resources or environment. Further, collectivism would relate to giving weight to values and beliefs advocated by one's community, locality, village, or neighbourhood while making economic decisions. With changing demographic features now, Indians are more interested in owning things for pleasure. Materialism implies enjoying the luxuries of life and giving due weightage to owning a house, car, and other material goods. In India, attitude towards risk is changing, and it is related to the change in economic, society and profile of the population. As mentioned above, the present study is destined to examine the relationship between individual attributes, i.e., religiosity, environmental attitude, collectivism, materialism, risk tolerance and social 
investing efficacy, and non-economic goal setting or investors' behaviour towards socially responsible investments.

\subsection{Defining Different Attributes of Individual Investor's Characteristics Contemplated}

Considering the relevance of factors mentioned above and after obtaining evidence from the literature survey, the study under consideration is confined to examining the impact of following factors on the determination of socially responsible investment behaviour of individuals, which is reflected through non-economic goals of individuals.

Religiosity: Research conducted by Sood and Nasu (1995), Johnson, Jang, Larson and Li (2001), Essoo and Dibb (2004) and Lindsay (2007) documented that an individual's dedication towards religion is reflected in his behaviour and all decision. Religion affects a person' values and attitudes, and these are personal. Religion and economic decision have been found as mutually exclusive (Zerubavel, 1991), but later, these two are also seen as influencing each other (Lindsay, 2007). Many times, it is noticed that the individuals do not prefer their investment in some 'negative list' industries. These are the companies, which are producing harmful products under the category of 'sin' by the definition of religion. The increasing importance of Islamic finance is also an example to understand the relationship between religion and investment behaviour. Similarly, Islamic funds exclude companies involved in products that deal with beef or alcohol. The attention paid by Islamic mutual fund managers to social responsibility aspect is a beautiful case of understanding the importance of religiosity in decision making (Abdelsalam et al., 2014). Du et al. (2014a) found that religious belief affects the investment decision in socially responsible investment alternatives. A company located in a community having firm religious belief gives more charity. Klein, Turk, Weill (2017) also stated that religion affects the investment decision of an individual. Therefore, empirical research has shown a strong positive association between business ethics and religiosity (Mokhlis, 2006). Li et al. (2019) examined the impact of religious belief on entrepreneurs' decision making. Socially responsible investments and religious belief affect the cost of debt of a firm too, and the religious belief of an entrepreneur affects its decision of raising debt. Usually, individuals' having religious belief have a low cost of debt, and the importance of religion to an individual affects his behaviour and attitude. Thus, the present study proposes the following hypothesis.

\section{H1: Religiosity has a significant impact on non-economic goals of individuals.}

Environmental Attitude: The companies' efforts towards green marketing imply that the consumers' attitude towards the environment is changing. The environmental concerns have influenced the finance and investment aspects too. Although the wakefulness towards environmental concerns is very low, now individuals have begun paying attention to green concepts of the companies. Poloinsky et al. (1995), Bidappa and Kaul (2011) are few studies among many which have focused on the green practices. The environment externalities affect the decisions of both environmentconscious investors and companies following environment-friendly practices. The cost of capital for raising equity by such company is less in consideration to meet the risk of environmental externalities. Likewise, investors also think of premium for bearing environment risk while selecting an equity portfolio for them (Kakeu, 2017). So, the literature supports that the environmental attitude may have a positive relationship with the individual's choice of non-economic goals.

H2: Environmental attitude has a significant impact on non-economic goals of individuals.

Collectivism: Hofstede (1980), Diltz (1995), Wagner (1995), Sirmon and Lane (2004), Ramamoorthy et al. (2005 and 2007), Kulkarni, et al., 2010 have supported the evidence that individualism and collectivism affect the cultural differences and hence the behaviour of individuals. Many of these studies say that the cultural differences in social behaviour in several countries are because of individualism-collectivism (IC). The individual investors' behaviour is affected by the culture to which they belong. In a research-based on nine European countries, i.e., Austria, Sweden, Denmark, Belgium, Greece, Finland, Portugal, Norway, and Ireland, the authors found that culture has a 
significant impact on investors' response to risk (Lee et al., 2018). In the Indian context, Collectivism has been ascribed to the Indian culture's prominence on family, sense of empathy and community (Kulkarni et al., 2010). Finding cues from these studies, the present study has also considered collectivism as a vital attribute affecting the individuals' decision making.

\section{H3: Collectivism has a significant impact on non-economic goals of individuals.}

Materialism: Materialism is related to an individual's worldly possessions. Voluminous studies have documented a negative correlation between materialism and non-economic goals. Material possession may have a different meaning for different individuals, and they interpret these possessions differently depending on their own possession of material things (Sagiv and Schwartz, 2000). Highly materialistic individuals tend to spend more on consumption to corroborate social expectations, while low materialists are projected to have less material possession for a sense of belongingness. Numerous studies, Belk (1984), Richins \& Dawson (1992), and Chatterjee, Hunt and Kernan (2000) are among the early studies documenting the relationship between materialism and individual's decision making. Contemplating the prominence of materialism, the following hypothesis has also been tested. The financial market is also affected by materialism. Both individuals and institutional investors behaviour are influenced by attributes like materialism and post-materialism (Jordaan, Dima and Golet, 2016; Alesina and Giuliano, 2015).

\section{H4: Materialism has a significant impact on non-economic goals of individuals.}

Risk Tolerance (Individual Risk Propensity and Individual Risk Affinity): Different individuals have different risk tolerance. Most individuals undertake investments with an objective of future reward. However, the size and certainty of reward are not fixed. The investors do not behave rationally all the time. The risk tolerance of an individual is dependent upon how the individual assesses risk and uncertainty. In simple terms, in case of well-known events, the risk is less and when an individual dread of something, then the quantum of risk increases. Moreover, this perception of risk is also swayed by the community culture and social norms. The tendency to bear risk and preference for an opaque situation specifies the risk tolerance capacity of the individuals. However, Kahneman and Tversky (1974) and Slovic et al. (1982) documented that individuals assess the risk in different ways. Consequently, they are not rational in every decision taken by them. Baxi (2011) conducted a study on the Asian Pacific region and concluded that Indian investors are less risk-taking as compared to others in this region. The responsible investors use the term 'grrenium' which they expect as a reward for bearing risk in investing in responsible enterprises (Patridge and Medda, 2020). The present study measure risk tolerance of the individual's inclination to take the risk or individual risk propensity and preference for vague circumstances. In lieu of this discussion, the following additional hypotheses have been examined.

H5a: Individual risk propensity has a significant impact on non-economic goals of individuals.

H5b: Individual risk affinity has a significant impact on non-economic goals of individuals.

Social Investing Efficacy (SIE): Block and Keller (1995), Diamond \& lyer (2007) and lyer and Kashyap (2009) documented how perceived effectiveness/efficacy influence the individual attitude and behaviour on various issues. SIE is one's view that one's actions will be able to get a much-required societal change. As per the Protection Motivation Theory proposed by Rogers (1975), effectiveness is significant to bring about a change in behaviour and attitude of the individuals. If an individual has this perception that his/her actions will do well for society, then he/she will do good for society by taking reasonable actions. The responsible individuals believe that their environmental concern can force companies to take actions to follow the green and responsible actions (Zavali and Theodoropoulou, 2018). SIE is supported by how strongly a person believes that their investment strategies would be capable of influencing corporate behaviour. Having such a belief investor can transmit their social values to the corporations by adopting appropriate investment strategies. Such 
characteristics guide investors to have a trade-off between economic and non-economic goals. SIE influences the force of the relation between investor characteristics and the quest for noneconomic goals. The role of social investing efficacy is examined as a mediating variable too. Therefore, two hypotheses were established as under.

H6a: Social investing efficacy has a significant impact on non-economic goals of individuals.

H6b: Social investing efficacy has a mediating effect on the relationship between individual investors' characteristics and their non-economic goals.

\section{Sampling Design and Data Collection}

\section{Table 1: Profile of respondents}

\begin{tabular}{lcc}
\hline Profile of respondents & $\begin{array}{c}\text { Number of } \\
\text { respondents }\end{array}$ & $\begin{array}{c}\text { Percentage of } \\
\text { respondents }\end{array}$ \\
\hline Gender & 304 & 80.42 \\
Male & 74 & 19.58 \\
Female & $\mathbf{3 7 8}$ & $\mathbf{1 0 0 . 0 0}$ \\
\hline Total & & \\
\hline Education/Qualification & 34 & 8.99 \\
Up to matriculation & 118 & 31.22 \\
Undergraduate & 87 & 23.02 \\
Undergraduate with a professional degree & 39 & 10.32 \\
Postgraduate & 81 & 21.43 \\
Postgraduate with a professional degree & 19 & 5.03 \\
PhD. & 378 & 100.00 \\
\hline Total & & 15.34 \\
\hline Amount of investment per year (INR) & 58 & 30.95 \\
>=5 Lakh & 117 & 24.60 \\
5 lakh-10 lakh & 93 & 18.78 \\
10 lakh-15 lakh & 71 & 10.32 \\
15 lakh-20 lakh & 39 & $\mathbf{1 0 0 . 0 0}$ \\
Above 20 lakh & 378 & 12.96 \\
\hline Total & & 17.72 \\
\hline Experience of Investment & 49 & 41.01 \\
5-6 years & 67 & 28.31 \\
6-7 years & 155 & $\mathbf{1 0 0 . 0 0}$ \\
7-8 years & 107 & \\
More than 8 years & $\mathbf{3 7 8}$ & \\
\hline Total & & \\
\hline Souce: Authr's & & \\
\hline
\end{tabular}

Source: Author's compilation

The study under consideration is based on primary data, which is collected through a survey, i.e., both online and offline. Total of 500 respondents was targeted, and the final sample composed of 378 respondents only as the rest of the respondents either provided incomplete information or did not respond in the set time frame. The sample consisted of only those respondents having more 
than five years' experience of investing in various financial and non-financial assets. The required data is collected from Tricity (Chandigarh-Mohali-Panchkula). Chandigarh contributes INR 2,517 crore as cash turnover and in the list of top 20 cities in BSE cash segment and Tricity contributes INR 28,005 crore in cash turnover at NSE and hold a place in top 20 cities in this segment at NSE (Source: Security Exchange Board of India, Annual Report, 2018-19, www.sebi.gov.in). A convenience sampling method was adopted to collect the data and investors visiting various banks, brokerage houses and financial advisers were targeted to collect information. We followed best practices to control the researchers' biases in selecting the respondents. Table 1 given below describe the profile of respondents. A structured questionnaire was taken as an instrument of data collection. The questions were asked on a seven-point Likert scale anchored at "Strongly Disagree" and "Strongly Agree" to measure the constructs. Individual characteristics of the investors were measured using scales with three to eight items. The collected data was tested for reliability analysis, and all scale items were found in the acceptable range for Cronbach's alpha (More than 0.68).

\subsection{Data Analysis Tool}

In order to empirically test the hypotheses, the present study has applied a hierarchical multiple regression model. The regression model applied on the survey data has considered non-economic goals of the investors as dependent variable and religiosity, environmental attitude, collectivism, materialism, risk propensity and risk affinity as independent variables. The social investing efficacy has been used as a mediating variable. Baron and Kenny (1986) gave a four-step method of testing the mediation. Under this, the regression coefficients are calculated, and their significance is tested at each step. Table 2 has explained the four-step process of testing mediation. The $C^{\prime}$ in the above equation indicates the direct effect.

\section{Table 2: Steps of Mediation Effect}

\begin{tabular}{|c|c|c|}
\hline & Analysis & Visual Depiction \\
\hline Step I & $\begin{array}{l}\text { Conduct a simple regression analysis with } \mathrm{X} \text { predicting } \mathrm{Y} \\
\text { to test for path c alone, } Y=B_{O}+B_{1} X+e\end{array}$ & $\stackrel{+}{\mathrm{X}}$ \\
\hline Step 2 & $\begin{array}{l}\text { Conduct a simple regression analysis with } \mathrm{X} \text { predicting } \mathrm{M} \\
\text { to test for path a, } M=B_{O}+B_{1} X+e\end{array}$ & $\mathrm{x} \longrightarrow \mathrm{a}$ \\
\hline Step 3 & $\begin{array}{l}\text { Conduct a simple regression analysis with } \mathrm{M} \text { predicting } \mathrm{Y} \\
\text { to test the significance of path } \mathrm{b} \text { alone, } \\
Y=B_{O}+B_{1} M+e\end{array}$ & $\mathrm{M} \longrightarrow \mathrm{Y}$ \\
\hline Step 4 & $\begin{array}{l}\text { Conduct a multiple regression analysis with } \mathrm{X} \text { and } \mathrm{M} \\
\text { predicting } \mathrm{Y}, Y=B_{O}+B_{1} X+B_{2} M+e\end{array}$ & \begin{tabular}{c}
\multicolumn{1}{c}{} \\
$\mathrm{X}$ \\
$\mathrm{M} \longrightarrow \mathrm{Y}$ \\
$\mathrm{b}$
\end{tabular} \\
\hline
\end{tabular}

If the first three equations result in one or more insignificant relationships, then it is said that no mediation effect is found. And assuming that some significant relationship is found in first three steps and one move to step four, some mediation is said to exist if the effect of $M$ remains significant after controlling for $X$. If even after controlling the $M$, the $X$ remains insignificant then the findings will support full mediation and still if $X$ remains significant, the findings will support only partial mediation. In the context of the present study, four regression models have been run, as mentioned above. 
The regression results thus obtained will help us to understand the following:

- Relationship between the mediator and independent variables,

- Relationship between mediator and outcome variable, and,

- Relationship of independent variable with the outcome variable with and without the mediating variable.

\section{Findings of the Study}

As stated above, the analysis begins with establishing a causal relationship between mediator variable, i.e., SIE (Social Investing Efficacy) and independent variables, i.e., religiosity, environment attitude, collectivism, materialism, individual risk propensity and individual risk affinity. The SIE is the dependent variable, and individual attributes of investors are independent variables. The regression results are mentioned in Table 3 given below. The results have reported that Environmental Attitude $(\beta=0.515, \dagger=4.696)$ and Collectivism $(\beta=0.228, \dagger=2.139)$ were found significantly at $5 \%$ level of significance. It indicates, environmental attitude and collectivism significantly affect the social investing efficacy attribute of individual investors.

Table 3: Regression Result of Social Investing Efficacy on Individual Variables

\begin{tabular}{|c|c|c|}
\hline 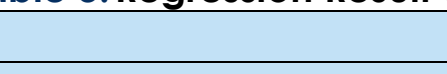 & Beta Coefficient & 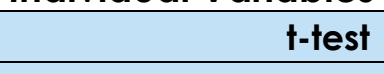 \\
\hline Religiosity & 0.107 & 1.216 \\
\hline Environmental Attitude & 0.515 & $4.696^{*}$ \\
\hline Collectivism & 0.228 & $2.139 *$ \\
\hline Materialism & 0.029 & 0.289 \\
\hline Individual Risk Propensity & 0.106 & 1.207 \\
\hline Individual Risk Affinity & -0.069 & -.767 \\
\hline R-Square & & 0.689 \\
\hline Adjusted R-Square & & 0.671 \\
\hline
\end{tabular}

*significant at $5 \%$ level.

Religiosity $(\beta=0.107, \dagger=1.216)$, Materialism $(\beta=0.029, \dagger=0.289)$, Individual risk Propensity $(\beta=0.106$, $\dagger=1.207)$ and Individual risk affinity $(\beta=-0.069, \dagger=-0.767)$ were found statistically insignificant. The individual attributes of investors taken in the study have judicially explained the SIE variable as adjusted $\mathrm{R}$-square is found 0.671 which is fairly acceptable when compared with related studies (lyer and Kashyap, 2009 reported adjusted R-square =0.11. Misra Srivastava \& Banwet (2019) reported adjusted R-square $=0.145$ and 0.275 ). Next, Table 4 has disclosed the regression results attained for the relationship between a median variable and the outcome variable. In other words, the next regression results were obtained for the impact of SIE variable on non-economic goals of investors. The social investing efficacy $(\beta=0.746, \dagger=11.703)$ was found significant at the 5 per cent level. Hence, it has a significant impact on setting the non-economic goals of individuals. The outcomes of this regression result supported the arguments in favour of hypothesis $\mathrm{H} 6$, and henceforth, it can be stated that Social Investing Efficacy significantly affects the non-economic goals of individual investors. 
Table 4: Regression Results from Non-economic Goals on Social Investing Efficacy

\begin{tabular}{|c|c|c|}
\hline & Beta Coefficient & t-test \\
\hline Social Investing Efficacy (SIE) & 0.746 & $11.703^{*}$ \\
\hline R-Square & & 0.557 \\
\hline Adjusted R-Square & & 0.553 \\
\hline
\end{tabular}

*significant at $5 \%$ level.

In the end, the impact of individual investors' attributes is examined on their non-economic goals and impact of the mediating variable (SIE) is tested. All these results are reported in Table 5. Column (1) and (2) have shown the results of direct effect, i.e., direct effect of individual investors' attributes on their non-economic goals and column (3) and (4) have shown the indirect effect or effect of mediation (SIE) of The religiosity $(\beta=0.282, \dagger=3.049)$ and environmental attitude $(\beta=0.301, \dagger=$ 2.610) were found significantly and positively affecting noneconomic goals of investors while collectivism ( $\beta=0.149, \dagger=1.431)$, materialism $(\beta=-0.078, \dagger=-0.709)$, individual risk propensity $(\beta=$ $0.057, \dagger=0.617)$ and individual risk affinity $(\beta=0.157, \dagger=1.654)$ were found statistically insignificantly. The adjusted R-square is found at 0.653 . Accordingly, the regression results have supported the first two hypotheses related to religiosity and environmental attitude, i.e., $\mathrm{Hl}$ and $\mathrm{H} 2$ are accepted while the statements of hypotheses mentioned in $\mathrm{H} 3, \mathrm{H} 4, \mathrm{H} 5 \mathrm{a}$ and $\mathrm{H} 5 \mathrm{~b}$ are not supported by these regression results.

Table 3: Regression Result of Social Investing Efficacy on Individual Variables

\begin{tabular}{|c|c|c|c|c|}
\hline & $\begin{array}{c}\text { Beta } \\
\text { Coefficient } \\
\text { (1) }\end{array}$ & $\begin{array}{l}\text { t-test } \\
(2)\end{array}$ & $\begin{array}{c}\text { Beta } \\
\text { Coefficient } \\
(3)\end{array}$ & $\begin{array}{c}\text { t-test } \\
\text { (4) }\end{array}$ \\
\hline Religiosity & 0.282 & $3.049 *$ & 0.247 & 2.778* \\
\hline Environmental Attitude & 0.301 & $2.610^{*}$ & 0.134 & 1.107 \\
\hline Collectivism & 0.149 & 1.431 & 0.140 & 1.403 \\
\hline Materialism & -0.078 & -0.709 & -0.004 & -0.035 \\
\hline Individual Risk Propensity & 0.057 & 0.617 & 0.023 & 0.256 \\
\hline Individual Risk Affinity & 0.157 & 1.654 & 0.144 & 1.416 \\
\hline Social Investing Efficacy (SIE) & & & 0.323 & $3.280^{*}$ \\
\hline R-Square & \multicolumn{2}{|c|}{0.657} & \multicolumn{2}{|c|}{0.689} \\
\hline Adjusted R-Square & \multicolumn{2}{|c|}{0.653} & \multicolumn{2}{|c|}{0.668} \\
\hline
\end{tabular}

*significant at $5 \%$ level.

Further, the next regression model was run on non-economic goals as the dependent variable, and individual investors' attributes were taken as independent variables in the presence of social investing efficacy as mediator. The coefficients obtained with the mediation effect were also found attenuated. Religiosity $(\beta=0.247, t=2.778)$, environmental attitude $(\beta=0.134, \dagger=1.107)$, collectivism $(\beta=0.140, \dagger=1.403)$, materialism $(\beta=-0.004, \dagger=-0.035)$ and risk tolerance [individual risk propensity $(\beta=0.023, \dagger=0.256)$, and individual risk affinity $(\beta=0.144, \dagger=1.416)]$ were lower than the coefficient found in regression without considering social investing efficacy (SIE) as a mediator variable. The Rsquare with mediation effect is improved in the second regression model, i.e., 0.668. It supports H6b, i.e., the existence of mediation effect, but this effect is not found significant for all variables. The impact of social investing efficacy (SIE) is also found significant with at-coefficient 3.280 and improved adjusted R-square (0.668). The results thus obtained confirm the existence of partial mediation in case of religiosity and full mediation effect in case of remaining variables. 


\section{Conclusion and Discussion}

SRI has been effectively executed in different parts of the world, but in case of India, albeit a prudently developed capital market and a culture of active investment decisions among the Indian individuals, there are only a few socially responsible funds available in for investors. The findings of the current study can be recapitulated as under. The results have indicated that religiosity is one of the significant antecedents to individual investor's non-economic goals in India. It indicates that the investors do not prefer a company producing and selling products, which is considered as 'sin' product. Religiosity drives the Indian investor's pursuit of non-economic goals, which is reflected by the excellent performance of Shariah funds in Indian markets. The results obtained for religiosity are in conformity with the evidence obtained by lyer and Kashyap (2009). But in case of the impact of religiosity on SIE (social investing efficacy), the results are contradictory. The present study has not supported a significant impact of religiosity on social investing efficacy of individual investors while opposite results were obtained by lyer and Kashyap(2009). Likewise, the current research has shown a prominent and significant impact of environmental attitude and collectivism on SIE while lyer and Kashyp (2009) indicated that collectivism and individual risk propensity are insignificant variables and remaining all attributes have a significant impact on noneconomic goals of investors. Misra, Srivastava \& Banwet, (2019) also produced evidence in favour of a significant impact of religion on individual investor's decision making. Another significant attribute of current research in environmental attitude. But its effect got vanished due to the mediating variable. Many other researchers have also stated the increasing concern of investors for the environment and green practices adopted by the corporate (Kakeu, 2017; Edmans, 2011). Further, while studying the direct relationship between individual attributes and non-economic goals of investors, the collectivism has also been found as a significant attribute affecting the investors' decisions regarding non-economic goals. Evidence is reported for other European countries, too, where the impact of culture is found significant on an individual's decision making (Lee et al., 2018). But current research has produced results in contrast to this and collectivism is found as an insignificant attribute. The conclusions are quite robust as expected and need further investigation. The social investing efficacy has been found as significant and positively related coefficient affecting the individuals' socially responsible investing behaviour. The SIE has a partial mediation effect on religiosity and full mediation effect on other individual attributes.

\section{Implications of the Findings}

The findings of the present study will be useful for fund managers to understand that individual investor decision is just like any other consumer choice process and there are several factors which influence the decision of the individuals' while setting their non-economic goals. Fund houses need to recognise the ethics that would impel Indian investors to pursue non-economic goal by investing in SRI funds. Many Indian corporations have already started considering this as part of their corporate social responsibility. Such initial talks in India are giving an indication that there will be a paradigm shift in investors' awareness as well as perception regarding socially responsible investment avenues and more fund managers will come forward with a strategy of offering socially responsible investment funds for investors. 


\section{References}

Abdelsalam, O., Fethi, M.D., Matallin, J.C., Tortosa-Ausina, E., 2014. On the comparative performance of socially responsible and Islamic mutual funds. Journal of Economic Behavior \& Organization 103, 108128.

Baron, R. M., \& Kenny, D. A., 1986. The moderator-mediator variable distinction in social psychological research: Conceptual, strategic, and statistical considerations. Journal of Personality and Social Psychology, 51, 1173-1182.

Bartolacci, F., Paolini, A., Quaranta, A. G., \& Soverchia, M. 2018. The relationship between good environmental practices and financial performance: Evidence from Italian waste management companies. Sustainable Production and Consumption, 14, 129-135. doi:10.1016/j.spc.2018.02.002

Baver, R., Smeets, P., 2012. Social Preferences and Investor Loyalty, Working Paper, Maastricht University.

Baxi, P.V., 2011. Cross cultural differences in financial risk-taking: India and the United States. available at: $\quad$ http://deepblue.lib.umich.edu/bitstream/handle/2027.42/85313/pvbaxi.pdf;jsessionid D65A0E48511122D7A91DB097F5E18865?sequence

Beal D.J., Goyen M., Phillips P., 2005. Why do we invest ethically? Journal of Investing, 14:66-77. DOI: 10.3905/joi.2005.580551

Belk, R.W., 1984. Three Scales to Measure Constructs Related to Materialism: Reliability, Validity, and Relationships to Measures of Happiness. Advances in Consumer Research, Association for Consumer Research, Utah, 11, 291-297.

Bidappa, R., Kaul, T.M., 2011. Indian Consumers Conscious of Environmental Benefits of Sustainable Practices. available at: http://www.nielsen.com/in/en/news-insights/pressroom/ 2011/indianconsumers-conscious-of-environmental-benefits.html (Accessed on February 1, 2013).

Block, L.G., Keller, P.A., 1995. When to accentuate the negative: the effects of perceived efficacy and message framing on intentions to perform a health-related behaviour. Journal of Marketing Research, 32, 192-203.

Brophy, M., 2015. Spirituality Incorporated: Including Convergent Spiritual Values in Business. Journal of Business Ethics, 132 (4), 779-94.

Chatterjee, A., Hunt, J.M., Kernan, J.B., 2000. Social character of materialism. Psychological Reports, 86 , $1147-1148$.

Corbridge, S., \& Harriss, J., 2013, Reinventing India: Liberalisation, Hindu Nationalism and Popular Democracy. Hoboken, NJ: John Wiley \& Sons.

Cortez, M. C., Silva, F., Areal, N. 2012. Socially responsible investing in the global market: The performance of US and European funds. International Journal of Finance \& Economics, 17(3), 254-271.

Cui, J., Jo, H., \& Velasquez, M. G., 2015. The Influence of Christian Religiosity on Managerial Decisions Concerning the Environment. Journal of Business Ethics, 132 (1), 203-31.

Dhawan, N., Roseman, I.J., Naidu, R.K., Rettek, S.I., 1995. Self-concepts across two cultures: India and the United States. Journal of Cross-Cultural Psychology, 26, 606-621.

Diamond, W.D., Iyer, E.S. 2007. Creating effective direct mail charitable solicitations: the effects of enclosures and different appeals. Journal of Nonprofit \& Public Sector Marketing, 18, 81-100.

Diltz, J.D., 1995. Does Social Screening Affect Portfolio Performance? Journal of Investing, 4, $64-69$.

Douglas, M., Wildavsky, A., 1982. Risk and Culture, University of California Press, Berkeley. The Economic Times, 2011, Indian investors less risk-taking than Asia-Pacific peers: Peter Brooks, Barclays Wealth available at http://articles.economictimes.indiatimes.com/2011-07-30/news/29833284_1_barclayswealth-investor-behaviour-risk-taking, (Accessed on Sept 26, 2012).

Du, X., Jian, W., Zeng, Q., \& Du, Y. 2014. 'Corporate Environmental Responsibility in Polluting Industries: Does Religion Matter? Journal of Business Ethics, 124(3), 485-507. 
Eccles, N.S., Viviers, S., 2011. The origins and meanings of names describing investment practices that integrate a consideration of ESG issues in the academic literature, Journal of Business Ethics, 104(3), 389402.

Essoo, N., Dibb, S. 2004. Religious influences on shopping behaviour: An exploratory study. Journal of Marketing Management, 20, 683-712.

European Sustainable and Responsible Investment Forum-Euros if. 2012. European SRI Study. Available at: http://www.eurosif.org/publications/sri_studies.

Ger, G., Belk, R.W. 1996. Cross-cultural differences in materialism. Journal of Economic Psychology, 17(1), 555-577.

Giannarakis, G., \& Theotokas, I., 2011. The Effect of Financial Crisis in Corporate Social Responsibility Performance. International Journal of Marketing Studies, 3(1), 1-8.

Goldberg, S. 1993. Social responsibility in mutual funds costly. The Sun Diego Union-Tribune (June 28): c-

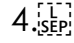

Gregory, R.P., Stead, J. G., \& Stead, E., 2020. The global pricing of environmental, social, and governance (ESG) criteria. Journal of Sustainable Finance \& Investment, DOI: 10.1080/20430795.2020.1731786

Herremans, I., Akathaporn, P., \& Mclnnes, M., 1993. An Investigation of Corporate Social Responsibility Reputation and Economic Performance. Accounting, Organisations \& Society, 18 (October-November), 587-604.

Hiraki, T., Inove, H., Ito, A., Kuroki, F., \& Masuda, H., 2003. Corporate governance and firm value in Japan: evidence from 1985 to 1998. Pacific-Basin Finance Journal 11, 239-265.

Hirschman, E. C., 1982. Religious Affiliation and Consumption Processes: An Initial Paradigm. in Research in Marketing (6), Jagdish Sheth, ed. Greenwich, CT: JAI Press, 131-70.

Hofstede, G., 1980, Culture's consequences: International differences in work-related values, Beverly Hills CA: Sage.

Hui, C.H., Triandis, H.C., 1986. Individualism-Collectivism: A Study of Cross-Cultural Researchers, Journal of Cross-Cultural Psychology, 17, 225-248.

lyer, E.S., Kashyap, R., 2009. Non-economic goals of investors. Journal of Consumer Behaviour, 8(5), 225237.

Jiang, F., Jiang, Z., Kim, K. A., \& Zhang, M., 2015. Family firm risk-taking: does religion matter? Journal of Corporate Finance, 33, 260-278.

Johnson, B.R., Jang, S.J., Larson, D.B., Li, S.D. 2001. Does adolescent religious commitment matter? A reexamination of the effects of religiosity on delinquency. Journal of Research in Crime and Delinquency, $38,22-43$

Kahneman, D., Tversky, A., 1974. Judgment Under Uncertainty: Heuristics and Biases, Science, 185, $1124-$ 1131

Kakeu, J., 2017. Environmentally conscious investors and portfolio choice decisions. Journal of Sustainable Finance \& Investment, 7(4), 360-378, DOI: 10.1080/20430795.2017.1326454

Klein, P-O., Turk, R., Weill, L., 2017. Religiosity vs. well-being effects on investor behavior. Journal of Economic Behavior and Organization, 138, 50-62. https://doi.org/10.1016/j.jebo.2017.04.009

Klein, T. A., Laczniak, G. R., \& Santos, N. J. C. 2017. Religion-motivated Enterprises in the Marketplace. Journal of Macro marketing, 37(1), 102-114. doi:10.1177/0276146716674050.

Kulkarni, S.P., Hudson, T., Ramamoorthy, N., Marchev, A., Kondakova, P.G. \& Gorskov, V. 2010. Dimensions of Individualism-Collectivism: A Comparative Study of Five Cultures. Current Issues of Business and Law, 5, 93-109.

Lee S., Switzer L. N., \& Wang J. 2018. Risk, Culture and Investor Behaviour in Small (but notorious) Eurozone Countries. Journal of International Financial Markets, Institutions \& Money. 60, 89-1 10.

Lindsay, D.M., 2007. Faith in the Halls of Power: How Evangelicals Joined the American Elite. Oxford University Press, New York. 
McGuire, J., Sundgren, A., \& Schneeweis, T., 1988. Corporate Social Responsibility and Firm Financial Performance. Academy of Management Journal, 31, 854-872.

McLachlan, J., and Gardner, J., 2004, A comparison of socially responsible and conventional investors, Journal of Business Ethics. 52, 11-25.

Mehta, P., 1994. Empowering the people for social Achievement. in R.N. Kanungo \& M. Mendonca (Ed.) Work Motivation Models for Developing Countries, Sage, New Delhi.

Misra, R., Srivastava, S., \& Banwet, D. K. 2019. Do religious and conscious investors make better economic decisions? Evidence from India. Journal of Behavioral and Experimental Finance. doi:10.1016/j.jbef.2019.02.003.

Miwa Nakai, M., Honda, T., Nishino, N., \& Takeuchi, K., 2018. Psychological characteristics of potential SRI investors and its motivation in Japan: an experimental approach. Journal of Sustainable Finance \& Investment, 8(4), 349-367, DOI: 10.1080/20430795.2018.1490556

Mokhlis, S. 2006. The effect of religiosity on shopping orientation: an exploratory study in Malaysia. Journal of American Academy of Business, 9(1), 67-74.

Mueller, S. 1991. The Opportunity Cost of Discipleship: Ethical Mutual Funds and Their Returns. Sociological Analysis, 52 (Spring), 111-124.

Pareek, U., 1986. Motivational analysis of organisations-behavior (MAO-B). in J. W. Pfeiffer \& L. D. Goodstein (Ed.), The 1986 annual: Developing human resources, San Diego, CA: University Associates.

Pennycook, G., Cheyne, J.A., Barr, N., Koehler, D.J., \& Fugelsang, J.A., 2014. Cognitive Style and religiosity: The role of conflict detection. Memory \& Cognition, 42(1), 1-10.

Poloinsky, M., J., Mintu-Wimsatt, A.T., 1995. Environmental Marketing: Strategies, Practice, Theory, and Research. Binghamton, NY: Haworth Press.

Ramamoorthy, N., Gupta, A., Sardessai, R.M., Flood, P.C., 2005. Individualism-collectivism and attitudes towards human resource systems: A comparative study of American, Irish and Indian MBA students, The International Journal of Human Resource Management, 16(5), 853-870.

Ramamoorthy, N., Kulkarni, S., Gupta, A., Flood, P., 2007. Individualism-collectivism orientation and employee attitudes: A comparison of employees from the high-technology sector in India and Ireland, Journal of International Management, 13, 187-203.

Renneboog L, Horst Ter J., Zhang C., 2008. The price of ethics and stakeholder governance: The performance of socially responsible mutual funds. Journal of Corporate Finance, 14(3), 302-322.

Renneboog, L., Ter Horst, J., Zhang, C., 2011. Is ethical money financially smart? Nonfinancial attributes and money flows of socially responsible investment funds, Journal of Financial Intermediation, 20(4), 562588.

Richins, M.L., \& Dawson, S., 1992. A Consumer Values Orientation for Materialism and its Measurement: Scale Development and Validation. Journal of Consumer Research, 19, 303-316.

Riedl, A., \& Smeets, P., (CESifo working paper) 2014. Social Preferences and Portfolio Choice. A., 2011 . Does the stock market fully value intangibles? Employee satisfaction and equity prices. Journal of Financial Economics 101, 621-640.

Rogers, R.W., 1975. A Protection Motivation Theory of Fear Appeals and Attitude Change. The Journal of Psychology, 91, 93-114.

Sagiv, L. \& Schwartz, S.H., 2000. Value priorities and subjective well-being: direct relations and congruity effects. European Journal of Social Psychology, 30(2), 177-198.

Saver, D. A. 1997. The impact of social-responsibility screens on investment performance: Evidence from the Domini 400 social index and Domini Equity Mutual Fund. Review of Financial Economics, 6(2), 137149. doi:10.1016/s1058-3300(97)90002-1

Schueth S., 2003. Socially Responsible Investing in the United States. Journal of Business Ethics43: $189-194$. DOI: 10.1023/A:1022981828869. 
Shavitt, S., Lalwani, A.K., Zhang, J., Torelli, C.J., 2006. The horizontal-vertical distinction in cross-cultural consumer research. Journal of Consumer Psychology, 16, 325-356.

Sirmon, D.J., Lane, P.J., 2004. A model of cultural differences and international alliance performance, Journal of International Business Studies, 35, 306-319.

Slovic, P., Baruch, F., Lichtenstein, S., 1982. Why Study Risk Perception? Risk Analysis 2, 83-93.

Social Investment Forum, 1995. After South Africa: Responsible Investing Trends in the United States.

Sood, J., \& Nasu, Y., 1995. Religiosity and Nationality: An exploratory study of their effect on consumer behaviour in Japan and the United States. Journal of Business Research, 34, 1-9.

Statman, Meir \& Glushkov, Denys. 2008. The Wages of Social Responsibility. Financial Analysts Journal, 65(4), 33-46.

Temper, J. 1991. The Cost of Social Criteria. Pensions \& Investments (May 13): 34.

Thomas, D.C., \& Au, K., 2002. The effect of cultural differences on behavioral responses to low job satisfaction. Journal of International Business Studies, 32, 309-326.

Wagner III, J.A., 1995. Studies of Individualism-Collectivism: Effect of Cooperation in Groups. Academy of Management Journal, 152-172.

Zerubavel, E., 1991. The Fine Line: Making Distinctions in Everyday Life. The Free Press, New York, NY.

Zuckerman, M., Silberman, J., \& Hall, J. A., 2013. The relation between intelligence and religiosity: a metaanalysis and some proposed explanations. Personality and Social Psychology Review, 17(4), 325-354 